\title{
William Lazonick
}

\section{Innovative Business Models and Varieties of Capitalism: Financialization of the U.S. Corporation}

How does economic organization affect economic performance? This analysis of the historical transformation of the U.S. economy from the business model of the "old economy" to that of the "new economy" demonstrates that the Japanese challenge of the 1980 s was an important catalyst for the shift. Anchored by the "Chandlerian" corporation, the old model delivered economic growth that was much more equitable and stable than the new one. Furthermore, the business model that underpinned the Japanese challenge represented a superior version of the old U.S. prototype. The financialization of corporate decision-making under the new paradigm has been the prime source of inequity and instability in U.S. economic performance over the past three decades. As manifested in outsized executive pay and massive stock buybacks, the financialization of the U.S. corporation threatens long-term economic growth.

$\mathrm{D}$

uring most of the twentieth century, the United States was generally viewed as a highly innovative economy that nations in other parts of the world sought to emulate. By the first decade of the twenty-first century, however, its reputation as an innovative economy has become severely tarnished. The country's income distribution has grown increasingly unequal, and its economic performance is unstable. ${ }^{1}$ Notwithstanding the United States' continued leadership in

WILLIAM LAZONICK is professor of economics at the University of Massachusetts, Lowell, and he is also affiliated with the University of Bordeaux.

${ }^{1}$ William Lazonick, "The New Economy Business Model and the Crisis of U.S Capitalism," Capitalism and Society 4, no. 2 (2009) (online journal); and Sustainable Prosperity in the New Economy? Business Organization and High-Tech Employment in the United States (Kalamazoo, Mich., 2009).

Business History Review 84 (Winter 2010): 675-702. (C) 2010 by The President and Fellows of Harvard College. 
high-technology industries, its capacity for continuous innovation is now in doubt. ${ }^{2}$

Has American capitalism changed? And if so, what "variety of capitalism" has the U.S. economy become? What institutional changes are needed to create a new form of U.S. capitalism that can generate equitable and stable economic growth?

No consensus has been reached in the debates about what American capitalism was, is, or should be. For example, in their well-known contribution to this debate, Peter Hall and David Soskice highlight the distinction between a "coordinated market economy," as exemplified by Germany's system, and a "liberal market economy," as exemplified by the one in the United States. Under the heading, "Liberal Market Economies: The American Case," Hall and Soskice, argue:

Liberal market economies [LMEs] can secure levels of overall economic performance as high as those of coordinated market economies, but they do so quite differently. In LMEs, firms rely more heavily on market relations to resolve the coordination problems that firms in CMEs [coordinated market economies] address more often via forms of non-market coordination that entail collaboration and strategic interaction. In each of the major spheres of firm endeavor, competitive markets are more robust and there is less institutional support for non-market forms of coordination. ${ }^{3}$

In effect, Hall and Soskice accept the conventional ideology that, in terms of the coordination of productive activity that results in superior economic performance, the United States-the world's largest and richest economy-can be understood as a "market economy" with a deregulated state. There are a number of problems with this perspective. First, to view the United States as essentially a "market economy" is to ignore the role of powerful business enterprises in the allocation of the economy's resources. As an illustration, in 2008 the top one thousand U.S.based business corporations categorized by revenues averaged over twelve billion dollars, and their employees worldwide numbered almost thirty-one thousand. Second, the U.S. government has always played a major role in funding the physical and human infrastructure that permits U.S. capitalism to operate at a high level of productivity. From this perspective, as I have argued elsewhere, during the twentieth century the United States possessed the most formidable "developmental state" in world history. ${ }^{4}$ Third, insofar as the deregulation of economic activity

\footnotetext{
${ }^{2}$ See, for example, Michael Mandel, "The Failed Promise of Innovation in the United States," BusinessWeek, June 3, 2009.

${ }^{3}$ Peter Hall and David Soskice, eds., Varieties of Capitalism: The Institutional Foundations of Comparative Advantage (Oxford, 2001), 27.
} 
and the rise of "flexible" capital and labor markets have brought a high degree of accuracy to the characterization of the United States as a "liberal market economy" over the past three decades or so, this variety of capitalism may, in fact, be resulting in inferior, not superior, economic performance.

Of course, the dominant role of corporations in the operation of the U.S. economy is nothing new. As Alfred Chandler documented in The Visible Hand (1977), by the 1920 s the managerial revolution in American capitalism had transformed the organization of the economy. ${ }^{5}$ Over the next half-century, the "Chandlerian" corporation put in place what I have called the "old-economy business model," characterized by oligopolistic competition, career employment with one company, and regulated financial markets. From the 1980s, however, this model began to break down, in part because of its own "financialization," which began with the conglomerate movement of the 1960s, and in part because of the rise of Japanese competition, starting in the 1970s. The Japanese competed successfully against the Americans in automobiles, consumer electronics, microelectronics, machine tools, and steel, industries in which the U.S. companies had been the world's leading mass producers. In effect, as I will argue in this essay, Japan outperformed the United States by perfecting the old-economy model.

The impacts of Japanese competition varied markedly across U.S. industries. It virtually wiped out the U.S.-based consumer-electronics industry. For example, in 1981, RCA was one of the leading consumerelectronics companies in the world, and the forty-fourth largest U.S. industrial company by revenues, employing 119,000 workers. By 1986, it had been taken over by General Electric and sold off in pieces. ${ }^{6}$ During the 1980 s, U.S. automobile manufacturers attempted to learn from the Japanese, but beginning in 2000 they were still producing lowerquality, higher-cost cars, and, not surprisingly, had lost significant market share. ${ }^{7}$ In the machine-tool industry, the overwhelming success of the Japanese against the major U.S. companies was followed from the

${ }^{4}$ William Lazonick, "Entrepreneurial Ventures and the Developmental State: Lessons from the Advanced Economies," World Institute of Development Economics Research, dp2008/ o1; available at http://www.wider.unu.edu/publications/working-papers/discussion-papers/ 2008/en_GB/dp2008-01/.

${ }^{5}$ Alfred D. Chandler Jr., The Visible Hand: The Managerial Revolution in American Business (Cambridge, Mass., 1977).

${ }^{6}$ Alfred D. Chandler Jr., Inventing the Electronic Century: The Epic Story of the Consumer Electronic and Computer Industries (New York, 2001), chs. 2 and 3.

${ }^{7}$ Michaela Platzer and Glennon Harrison, "The U.S. Auto Industry: National State Trends in Manufacturing Employment," Congressional Record Service Report, 7-5700, 3 Aug. 2009; "U.S. Vehicle Sales Market Share by Company, 1961-2008," at WardsAuto.com, http:// wardsauto.com/keydata/. 


\section{William Lazonick / 678}

1990 s on by the emergence of export-oriented small- and mediumsized enterprises producing for specialized niche markets. ${ }^{8}$ In the steel industry, the innovative response of the United States was the emergence of independent minimills, using electric-arc furnaces and scrap metal. In the 1980 s, the minimills only had the technological capability to manufacture long products, such as bars and rails, but under the leadership of the large U.S. steel manufacturer Nucor, compact strip-production technology was introduced in 1989, enabling minimills to compete with integrated mills in flat products, such as plates and sheets. ${ }^{9}$

The most important and successful U.S. response to Japanese competition was in the semiconductor industry. By the middle of the 1980s, the Japanese had used their integrated skill bases to lower defects and raise yields in the production of memory chips, forcing major U.S. semiconductor companies to retreat from this segment of the market. ${ }^{10}$ Led by Intel and its microprocessor for the IBM personal computer (PC) and its clones, U.S. companies became world leaders in chip design. Indeed, the IBM PC and its "Wintel" architecture laid the basis for the rise of what I have called the "new-economy business model," which by the year 2000 had relegated the old-economy model to history. ${ }^{11}$

A particular business model is defined by its strategy, organization, and finance. ${ }^{12}$ The contrasting strategic, organizational, and financial characteristics of the new- and old-economy models developed initially in the information and communication technology industries, as laid out in Table 1. Of particular importance to the rise of the new-economy model was the change in employment relations within high-tech sectors. Career employment across many companies replaced the pattern of lifetime employment in a single firm, a change that was encouraged by the move from proprietary technology standards to open technology standards. The proliferation of startups as a critical component in the rise of the new-economy model expanded the possibilities for job-hopping,

\footnotetext{
${ }^{8}$ Ronald Kalafsky and Alan MacPherson, "The Competitive Characteristics of the U.S. Machine Tool Industry," Small Business Economics 19, no. 4 (2002): 355-69.

${ }^{9}$ Frank Giarratani, Gene Gruver, and Randall Jackson, "Clusters, Agglomeration, and Economic Development Potential: Empirical Evidence Based on the Advent of Slab Casting by U.S. Steel Minimills," Economic Development Quarterly 21, no. 2 (2007): 148-64.

${ }^{10}$ Robert Burgelman, "Fading Memories: A Process Theory of Strategic Exit in Dynamic Environments," Administrative Science Quarterly 39, no. 1 (1994): 24-56; Daniel Okimoto and Yoshio Nishi, "R\&D Organization in Japanese and American Semiconductor Firms," in The Japanese Firm: Sources of Competitive Strength, ed. Masahiko Aoki and Ronald Dore (Oxford, 1994), 178-208.

${ }^{11}$ Lazonick, "The New Economy Business Model"; and Sustainable Prosperity in the New Economy?

${ }^{12}$ William Lazonick, "The Chandlerian Corporation and the Theory of Innovative Enterprise," Industrial and Corporate Change 19, no 2 (2010): 317-49; and Sustainable Prosperity in the New Economy?
} 
Table 1

Strategy, Organization, and Finance of the Old- and New-Economy Business Models

\begin{tabular}{|c|c|c|}
\hline & Old-Economy Model & New-Economy Model \\
\hline $\begin{array}{l}\text { Strategy, } \\
\text { product }\end{array}$ & $\begin{array}{l}\text { Growth by building on internal } \\
\text { capabilities; business } \\
\text { expansion into new product } \\
\text { markets based on related } \\
\text { technologies; geographic } \\
\text { expansion to access national } \\
\text { product markets. }\end{array}$ & $\begin{array}{l}\text { New firm entry into specialized } \\
\text { markets; sale of branded } \\
\text { components to system integrators; } \\
\text { accumulation of new capabilities } \\
\text { by acquiring young technology } \\
\text { firms. }\end{array}$ \\
\hline $\begin{array}{l}\text { Strategy, } \\
\text { process }\end{array}$ & $\begin{array}{l}\text { Corporate R\&D labs; } \\
\text { development and patenting } \\
\text { of proprietary technologies; } \\
\text { vertical integration of the value } \\
\text { chain, at home and abroad. }\end{array}$ & $\begin{array}{l}\text { Cross-licensing of technology based } \\
\text { on open systems; vertical } \\
\text { specialization of the value chain; } \\
\text { outsourcing and offshoring. }\end{array}$ \\
\hline Organization & $\begin{array}{l}\text { Secure employment: career with } \\
\text { one company; salaried and } \\
\text { hourly employees; unions; } \\
\text { defined-benefit pensions; } \\
\text { employer-funded medical } \\
\text { insurance in employment } \\
\text { and retirement. }\end{array}$ & $\begin{array}{l}\text { Insecure employment: interfirm } \\
\text { mobility of labor; broad-based } \\
\text { stock options; nonunion; defined- } \\
\text { contribution pensions; employee } \\
\text { bears greater burden of medical } \\
\text { insurance. }\end{array}$ \\
\hline Finance & $\begin{array}{l}\text { Venture finance from personal } \\
\text { savings, family, and business } \\
\text { associates; NYSE listing; } \\
\text { payment of steady dividends; } \\
\text { growth finance from retentions } \\
\text { leveraged with bond issues. }\end{array}$ & $\begin{array}{l}\text { Organized venture capital; initial } \\
\text { public offering on NASDAQ; low or } \\
\text { no dividends; growth finance from } \\
\text { retentions plus stock as acquisition } \\
\text { currency; stock repurchases to } \\
\text { support stock price. }\end{array}$ \\
\hline
\end{tabular}

Source: Lazonick, Sustainable Prosperity in the New Economy? 17.

especially when those startups were concentrated in high-tech industrial districts, such as Silicon Valley in California and Route 128 in Massachusetts. Enabling the rise of flexible labor markets in the 1980 os was the emergence of flexible capital markets in the form of venture capital, a phenomenon that took root in Silicon Valley in the 1970 s as a distinctive financial-services industry dedicated to the formation of new firms.

I will argue in this article, however, that the ways in which these flexible labor and capital markets were created to put the new-economy model in place had, by the decade beginning in 2000, resulted in institutions for the allocation of labor and capital that form the basis of the current fragility of the U.S. economy, in terms of both its own internal socioeconomic dynamics and its capability to respond to new global 


\section{William Lazonick / 680}

challenges. Specifically, as indicated in the categories listed under "Organization" and "Finance" in Table 1, the rise of the new-economy business model elevated the stock market to a position of far greater influence over the allocation of resources to innovative enterprise than it had occupied before. ${ }^{13}$

Under the old-economy model, the function of the stock market had been to separate ownership from control; the fragmentation of share ownership of publicly listed companies left salaried managers in positions of strategic control over the allocation of corporate resources. The separation of ownership from control occurs to some extent under the new-economy business model when companies list on the stock market. ${ }^{14}$ Under this more recent paradigm, however, the stock market also performs compensation and combination functions. Through the offer of what came to be known as "broad-based" stock-option plans, the rise of the new-economy model relied for its success on prospective stockmarket gains to induce professional, technical, and administrative labor to leave secure employment at established companies for insecure employment at startups. Through the possibility for doing an initial public offering (IPO) or a merger-and-acquisition deal, the rise of the neweconomy business model also relied on prospective stock-market gains to induce financial capital accumulated in the old economy to be transferred to the new economy in the form of venture capital.

In the process, as I will show, even the most innovative sectors of the U.S. economy have become highly financialized as the allocation of corporate resources is being driven by the ideology of "maximizing shareholder value." By financialization, I mean the evaluation of the performance of a company by a financial measure, such as earnings per share. The manifestation of the financialization of the U.S. economy is the obsession of corporate executives with distributing "value" to shareholders, especially in the form of stock repurchases, even if they accomplish this goal at the expense of investment in innovation and the creation of U.S. employment opportunities.

In the next section, I outline the main characteristics of the highly regulated old-economy business model in the post-World War II

\footnotetext{
${ }^{13}$ The stock market can perform five functions in the operation of the company that can be summarized as creation, control, combination, compensation, and cash. See Lazonick, "The New Economy Business Model."

${ }^{14}$ Under the new-economy business model, most companies list on NASDAQ, which has less stringent listing requirements than the New York Stock Exchange, thus tending to shorten the duration of time from company formation to initial public offering (IPO), which in turn tends to increase the prevalence of owner-entrepreneurs who still exercise a degree of control over the allocation of resources of the company after the IPO. Nevertheless, the participation of venture capital and the use of broad-based stock option plans in the new-economy model contribute to the separation of ownership from control at the IPO, and the tendency remains for the complete separation of ownership from control over time under the new model.
} 
decades when it was dominant in the United States. In the following section, I argue that the business model that enabled the Japanese to compete successfully against the Americans in a range of industries that had been dominated by the United States was a more innovative version of the old-economy model. Then I chart the rise of the new-economy business model as a response to the Japanese challenge, which, while it has generated innovation, has also been a source of inequity and instability because of its heavy reliance on the stock market for the operation of flexible capital and labor markets. Finally, I analyze how the "liberal market economy" that has emerged in the United States on the basis of the new-economy model generates inequitable and unstable economic performance that undermines the innovative capability of U.S. industry.

\section{The U.S. Old-Economy Model ${ }^{15}$}

The U.S. business model was dominant in global competition in the post-World War II decades. (See Figure 1.) A basic characteristic of this business model was the separation of share ownership and managerial control. The emergence of the New York Stock Exchange as a liquid national stock market during the first decades of the century resulted in the fragmentation of shareholding, leaving career managers in control of the allocation of resources in the nation's major corporations. In principle, boards of directors representing the interests of shareholders monitored the decisions of these managers; in practice, incumbent top executives chose the outside directors and were themselves members of the board. Shareholders could challenge management through proposals to the annual general meeting, but, over the course of the twentieth century, a body of law evolved that enabled management to exclude stockholder proposals that dealt with normal business matters (for example,

\footnotetext{
${ }^{15}$ For the main characteristics of the U.S. old-economy business model, see David F. Noble, America by Design: Science, Technology, and the Rise of Corporate Capitalism (New York, 1977); David Mowery and Nathan Rosenberg, Technology and the Pursuit of Economic Growth (New York, 1989); Alfred D. Chandler Jr., Scale and Scope: The Dynamics of Industrial Enterprise (Cambridge, Mass., 1990); Thomas P. Hughes, American Genesis: A Century of Invention and Technological Enthusiasm, 1870-1970 (New York, 1990); William Lazonick, Competitive Advantage of the Shop Floor (Cambridge, Mass., 1990), chs. 7-10; William Lazonick, "The Innovative Firm," in The Oxford Handbook of Innovation, ed. Jan Fagerberg, David Mowery, and Richard Nelson (Oxford, 2004), 29-55; David Brody, Workers in Industrial America: Essays on the Twentieth Century Struggle (Oxford, 1993, 2nd ed.); Nathan Rosenberg and Richard Nelson, "American Universities and Technological Advance in Industry," Research Policy 23, no. 3 (1994): 323-48; David Hounshell, "The Evolution of Industrial Research in the United States," in Engines of Innovation: U.S. Industrial Research at the End of an Era, ed. Richard Rosenbloom and William Spencer (Boston, 1996), 13-85; and Mary O'Sullivan, Contests for Corporate Control: Corporate Governance and Economic Performance in the United States and Germany (Oxford, 2000), chs. 3-6.
} 


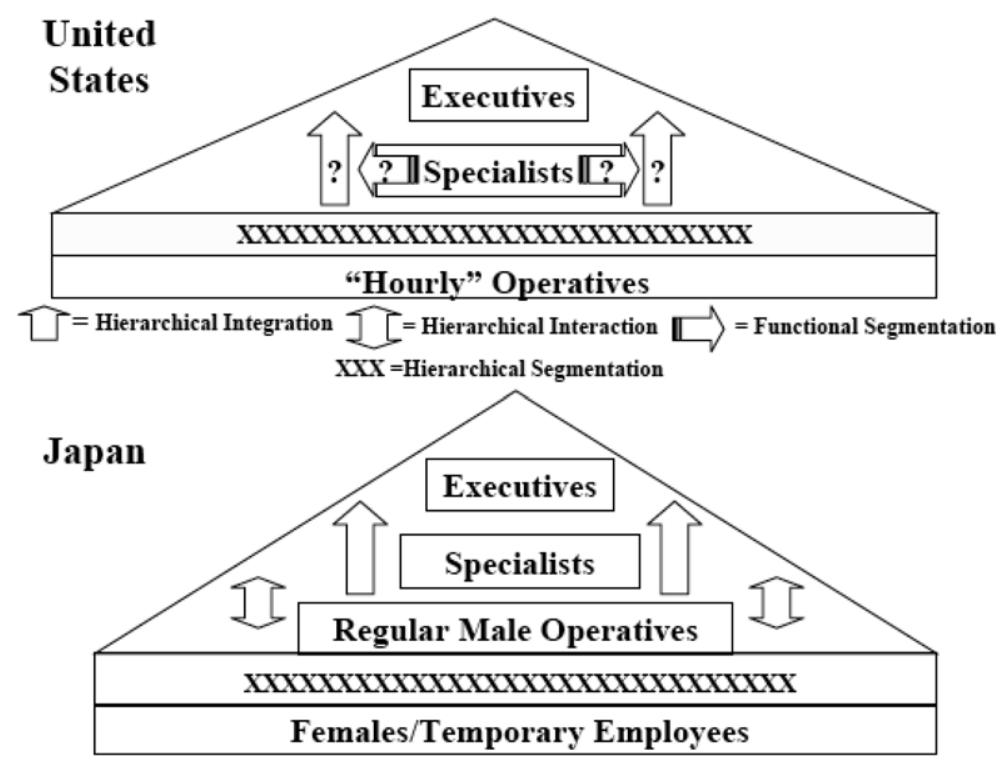

Figure 1. U.S. old-economy business model compared with the perfected Japanese version.

acquisitions or downsizings) as distinct from social issues (for example, sex discrimination or environmental pollution).

Having spent their careers with the companies that they came to head, top executives saw themselves as "organization men." As such, they tended to act in the interests of the organizations, rather than of just themselves; their own career success depended on the success of the whole enterprise. In the immediate post-World War II decades, the salaries of top executives of U.S. corporations remained constrained by the hierarchical salary structures of the managerial organizations over which they presided. Already in the 1950s, however, top executives of these companies were receiving stock options, a mode of compensation that, as I argue below, ultimately undermined the organizational integration of those in positions of strategic control.

The U.S. business model worked effectively to generate innovation when executives who exercised strategic control were integrated with an organization of administrative and technical specialists who engaged in the development and ensured the utilization of the company's productive resources. These organization men were on career paths along which they moved up and around a particular corporate hierarchy, with the possibility, even if not the high probability, that they would rise to top executive positions. These cohesive managerial structures 
encouraged the functional integration of the capabilities of administrative and technical specialists, contributing to the world's most formidable systems of mass production.

At the same time, however, a distinctive feature of the U.S. model was the organizational segmentation between, in the upper part of the hierarchy, salaried managers in whose training and experience the corporation made heavy investments, and, in the lower part, "hourly" workers who, while they often spent their entire working lives at one company, were considered interchangeable commodities in whose capabilities the company had no need to invest. ${ }^{16}$ Salaried managers entered these corporations with higher-education degrees from a wellfunded, government-supported system whose curricula had historically been shaped by the needs of business corporations for technical and administrative personnel. Hourly workers entered these corporations with high-school diplomas that generally reflected mediocre educations.

Nevertheless, union representation, seniority hiring and firing, overtime pay, the need of corporations for reliable, even if low-skilled, workers to tend mass-production processes, and the success of the U.S. model combined to enable these hourly workers to receive good pay and benefits. As a rule, however, the hourly worker could, over the course of his or her working life, at best hope to rise to the rank of foreman, a salaried position that denied these supervisors the right to be represented in collective bargaining and was generally a dead end in terms of any further career mobility up the managerial hierarchy. Meanwhile, a central preoccupation of salaried managers in the post-World War II decades was the development of skill-displacing automated technologies, so that in "the factory of the future" their companies could dispense with the employment of hourly workers whom they viewed as undereducated, underskilled, and overpaid.

The U.S. industrial corporation received considerable financial support from government programs for technology development in areas such as aerospace, computers, and life sciences. The development of the productive potential of these government investments relied on the corporate-research capabilities represented at companies such as AT\&T, DuPont, and GE, the world's leading corporate research labs. Retained earnings formed the financial foundation for the investments that the corporations made; in the 1960 s and 1970 s, corporate taxes were about 39 percent of corporate profits (including inventory valuation and capital consumption adjustments), dividends were about 25 percent,

\footnotetext{
${ }^{16}$ Nonsalaried employees are classified as "hourly" (or "nonexempt") workers because of the stipulation of the Fair Labor Standards Act of 1938 that requires employees who are paid an hourly wage to receive 150 percent of that wage if they work longer than the normal working hours. The overtime work of salaried personnel is exempt from this provision.
} 
and retentions were about 36 percent. When corporations needed additional investment financing, they issued corporate bonds at favorable rates that reflected conservative debt-equity ratios. Bank loans were used almost exclusively for working capital. Companies made only limited use of the stock market as a source of investment funds.

As I discuss below, during the 1970 s and 1980 s, the U.S. model began to falter in the face of Japanese competition that integrated shopfloor workers into the processes of organizational learning. In historical retrospect, as I have already remarked, the Japanese perfected the U.S. old-economy business model. In addition, the internal cohesion of the managerial organizations of U.S. corporations weakened, particularly as corporations grew bigger and diversified into many different lines of business. The conglomerate movement of the 1960 s separated top executives from the rest of the managerial organization. Increasingly, moreover, an integrative hierarchical reward structure ceased to regulate the pay of top executives, who embraced wholeheartedly the ideology of maximizing shareholder value as their boards bestowed on them ever more generous stock-option awards. At the same time, in the high-tech industries, younger professional, technical, and administrative personnel became less dependent on the pursuit of careers within old-economy corporate hierarchies, as the creation of new firms based on a neweconomy business model enabled them to take advantage of interfirm mobility by cultivating alternative career opportunities.

\section{The Japanese Challenge ${ }^{17}$}

In the 1970 s and 1980 s, the Japanese business model directly confronted the U.S. old-economy model depicted in Figure 1. In the post-

\footnotetext{
${ }^{17}$ This section draws on the following works: Eleanor Hadley, Antitrust in Japan (Princeton, 1970); Shinichi Yonekawa, "University Graduates in Japanese Enterprises before the Second World War," Business History 26, no. 3 (1984): 193-218; James C. Abegglen and George Stalk Jr., Kaisha: The Japanese Corporation (New York, 1985); Michael Cusumano, The Japanese Automobile Industry: Technology and Management at Nissan and Toyota (Cambridge, Mass., 1985); and Andrew Gordon, The Evolution of Labor Relations in Japan: Heavy Industry, 1853-1955 (Cambridge, Mass., 1985).

See also the following works by Ronald Dore: Flexible Rigidities: Industrial Policy and Structural Adjustment in the Japanese Economy, 1970-1980 (Stanford, 1986); Taking Japan Seriously: A Confucian Perspective on Leading Economic Issues (Stanford, 1987); British Factory, Japanese Factory: The Origins of National Diversity in Industrial Relations (Berkeley, 1990, 2nd ed.); and Stock Market Capitalism, Welfare Capitalism: Japan and Germany versus the Anglo-Saxons (Oxford, 2000).

See also: Kim Clark and Takahiro Fujimoto, Product Development Performance: Strategy, Organization, and Management in the World Auto Industry (Boston, 1991); Masahiko Aoki and Ronald Dore, eds., The Japanese Firm: Sources of Competitive Strength (Oxford, 1994); Okimoto and Nishi, "R\&D Organization in Japanese and American Semiconductor Firms"; Mari Sako and Hiroki Sato, eds., Japanese Labour and Management in Transition:
} 
World War II decades, U.S. managerial corporations dominated international competition in a wide range of high-technology industries. Many of these corporations had been accumulating innovative capabilities since the late nineteenth century. During the depressed years of the 1930s, even the U.S. industrial corporations that cut back production and employment dramatically nevertheless continued to invest in research and development and to enhance their innovative capability. Within the new structure of cooperative industrial relations that emerged out of the conflicts of the depression years, U.S. industrial corporations were able to take advantage of the post-World War II boom to reestablish themselves as the world's preeminent producers of consumer durables, such as automobiles and electric appliances, and related capital goods, such as steel and machine tools. With the help of U.S. government research support and contracts, U.S. companies also became the leaders in the computer and semiconductor industries.

Then, in the 1970s and 1980s, Japanese companies challenged the U.S. industrial corporations in the very industrial sectors in which, even as late as the 1960 , U.S. corporations seemed to have held insurmountable competitive advantage. Building on the development of innovative capabilities in their home market during the 1950 and 1960 s, Japanese companies gained competitive advantage over U.S. companies in industries such as steel, memory chips, machine tools, electric machinery, consumer electronics, and automobiles. Initially, as Japanese exports to the United States increased rapidly in the last half of the 1970 s, many observers attributed the challenge to the lower wages and longer working hours that prevailed in Japan. By the early 1980 s, however, as real wages in Japan continued to rise, it became clear that the Japanese advantage was based on superior capabilities for generating higher-quality, lower-cost products. In effect, by integrating shop-floor workers into the processes of organizational learning, which in turn

Diversity, Flexibility, and Participation (London, 1997); and Hidemasa Morikawa, A History of Top Management in Japan: Managerial Enterprises and Family Enterprises (Oxford, 2001).

And the following by Lazonick: "Strategy, Structure and Management Development in the United States and Britain," in Development of Managerial Enterprise: Proceedings of the Fuji Conference, ed. Kesaji Kobayashi and Hidemasa Morikawa (Tokyo, 1986), 101-46; "Cooperative Employment Relations in Manufacturing and Japanese Economic Growth," in Capital, the State, and Labour: A Global Perspective, ed. Juliet Schor and Jong-Il You (Aldershot, 1995), 70-110; "Organizational Learning and International Competition," in Globalization, Growth, and Governance: Creating an Innovative Economy, ed. Jonathan Michie and John Grieve Smith (Oxford, 1998), 204-38; "The Japanese Economy and Corporate Reform: What Path to Sustainable Prosperity?” Industrial and Corporate Change 8, no. 4 (1999): 607-33; and "The Institutional Triad and Japanese Development" [in Japanese], in The Contemporary Japanese Enterprise, ed. Glenn Hook and Akira Kudo (Tokyo, 2005), 1: $55^{-82 .}$ 


\section{William Lazonick / 686}

fostered cross-functional integration among technical specialists within the managerial structure, the Japanese perfected the U.S. old-economy business model and beat the U.S. competitors at their own game.

Three business institutions-stable shareholding, permanent employment, and main-bank lending-provided the social conditions for Japan's remarkable success. ${ }^{18}$ Stable shareholding ensured that the top managers of Japanese industrial corporations would possess the strategic control required to make innovative investments in industries regarding which, in the 1950s, there was no inherent reason to believe in their ultimate success in international competition. Permanent employment allowed the companies involved to put in place a new model of hierarchical and functional integration that enabled them to engage in collective and cumulative learning in ways that their international competitors could not. Main-bank lending (described below) supplied these companies with a level of financial commitment that permitted them both to grow rapidly and to sustain innovation until they could generate returns first on home and then on foreign product markets.

In 1948, the supreme commander for the Allied powers-the occupation authority in Japan-began the dissolution of the zaibatsu, the giant holding companies that had dominated the Japanese economy from the Meiji era of the late nineteenth century to World War II. The dissolution not only dispossessed the families that owned the zaibatsu, but also removed from office the top management layers of the zaibatsu holding companies and major affiliates. Placed in positions of strategic control were middle managers, who had to find new uses for their companies' accumulated capabilities in nonmilitary markets.

To invest in the capabilities of their companies, enterprise managers needed to maintain as much control as possible over the allocation of corporate revenues. But the undeveloped state of the companies subsequent to the dissolution of the zaibatsu, and the structure of public shareholding, left Japanese enterprises vulnerable, if not to takeovers, then to debilitating demands from outside interests for the distribution of their earnings, if and when such earnings should appear. To defend themselves against demands for "shareholder value" by these outside interests, the community of corporate executives engaged in the practice of cross-shareholding. Banks and industrial companies took equities off the market by holding each other's shares. Increasingly, business relations among companies, both industrial and financial, became cemented by cross-shareholding arrangements, whereby a company that had closer relations with another company was more likely to hold

\footnotetext{
${ }^{18}$ These institutions are conventionally labeled "cross-shareholding," "lifetime employment," and "the main bank system," respectively. For reasons elaborated in Lazonick, "The Institutional Triad and Japanese Development," these conventional terms are misleading.
} 
larger amounts of that company's shares, up to the legal maximum of 5 percent of shares outstanding (or 10 percent in the case of holdings by insurance companies). Over time, as business relations among financial and industrial enterprises changed, the web of cross-shareholding became more intricate, so that mutual shareholding between two companies ceased to be an important feature of the system. What became important was the dense network of stable shareholding. The institution of stable shareholding is not based on contractual relations, but, rather, has been sustained by the willingness of the entire Japanese business community to accept that one company does not seek its own advantage by selling its shareholdings of another company to public shareholders. ${ }^{19}$ Japanese companies have routinely given their proxy votes to the managers of the companies whose shares they hold.

By 1955, according to its broadest, and most relevant, definition as stock in the hands of stable shareholders who would not unilaterally sell their shares on the market, stable shareholding represented 25 percent of outstanding stocks listed on the Tokyo Stock Exchange, and by 1960 it had risen to about 40 percent. It declined slightly in the early 1960 s, but after the Japanese capital markets opened up in 1964, when Japan joined the Organisation for Economic Co-operation and Development, the business community, fearing foreign takeovers, took steps to increase stable shareholding. It surpassed 60 percent in 1975, and remained above that figure until 2000, peaking at 67 percent in 1988 . During the recessionary years of the 1990 , there was a gradual decline of stable shareholdings to 62 percent in 1998, followed by a sharp drop to 57 percent in 2000. Financial institutions, burdened by mountains of nonperforming loans and compelled to realize the value of their shares to restore capital-adequacy ratios, accounted for the vast majority of the sell-offs, while foreigners accounted for most of the increase in the proportions of all outstanding shares held. ${ }^{20}$

From the 1950s, corporate managers used the strategic control that stable shareholding protected to build organizations characterized by functional and hierarchical integration. (See Figure 1.) Critical to this organization building were the investments in an educated labor force that the Japanese government had made since the last decades of the nineteenth century. In the decades after the Meiji Restoration of 1868, the primary and secondary education of the entire population was

${ }^{19}$ When in financial distress, a company might raise cash by selling some of its stable shareholdings to other companies at the going market price, but with an understanding that the shares would be repurchased, also at the going market price, if and when its financial condition improved.

${ }^{20}$ The value of shares held by foreigners increased from 6 percent in 1992 to over 13 percent in 1998 to almost 28 percent in 2008. Tokyo Stock Exchange, Fact Book 2009 (2009), 61, available at http://www.tse.or.jp/english/market/data/factbook/index.html. 
raised to a high level. Simultaneously, a transformation of the system of higher education generated a growing supply of university graduates who entered industry. In addition to paying them well, the companies often incurred the considerable expense of sending these highly educated employees abroad for varying lengths of time to acquire industrial experience. As a result, in the aftermath of World War II, Japanese companies could draw on a sizable supply of highly educated and experienced engineers and managers.

Before the war, moreover, many Japanese companies had integrated foremen into the structure of managerial learning so that they could not only supervise but also train workers on the shop floor. Whereas in the United States, the foreman, as "the man in the middle," served as a buffer between the managerial organization and the shop floor, in Japan the foreman was an integrator of managerial and shop-floor learning. From the late nineteenth century, a prime objective of U.S. managerial learning had been to develop machine technologies that could dispense with the skills of craft workers. In contrast, because an accumulation of such craft skills was lacking in Japan, the problem that had confronted technology-oriented managers from the Meiji era was the development of skills on the shop floor as part of a strategy of organizational learning that integrated the capabilities of managers and workers.

The rise of enterprise unions in the early 1950 os both reflected and enhanced the social foundations for the hierarchical integration of shop-floor workers. During the last half of the 1940s, dire economic conditions and democratization initiatives gave rise to a militant labor movement of white-collar (technical and administrative) and bluecollar (operative) employees. The goal of the new industrial unions was to implement "production control": the takeover of idle factories so that workers could put them into operation and earn a living. As an alternative to these militant industrial unions, leading companies created enterprise unions of white-collar and blue-collar employees. In 1950, under economic conditions rendered more severe by the Occupation's anti-inflationary policies, companies such as Toyota, Toshiba, and Hitachi fired militant workers and offered enterprise unionism to the remaining employees. The post-Korean War recession of 1953 created another opportunity for more companies to expel the militants and introduce enterprise unionism.

Foremen and supervisors were members of the union, as were all university-educated personnel for at least the first ten years of employment, before they made the official transition into "management." Union officials, who were company employees, held regularly scheduled conferences with management at different levels of the enterprise to resolve issues concerning remuneration, work conditions, work organiza- 
tion, transfers, and production. The continued and rapid expansion of the Japanese economy in the high-growth era ensured that enterprise unionism would become an entrenched Japanese institution.

The most important achievement of enterprise unionism was "lifetime employment," a system of permanent employment that, while not contractually guaranteed, gave male white-collar and blue-collar workers employment security to the retirement age of, first, fifty-five; from the 1980s, sixty; and, from the late 1990 at a growing number of companies, sixty-five. This employment security both won the commitment of the workers to the company and gave the company the incentive to develop the productive capabilities of its workers. The system did not differ in principle from the organizational integration of professional, technical, and administrative employees that was at the heart of the U.S. managerial revolution, except in one extremely important respect. Unlike the United States where there was a sharp distinction between salaried managers and hourly workers, Japanese companies of the post-World War II decades extended permanent employment to both white-collar and blue-collar personnel, thus providing a foundation for the hierarchical integration of shop-floor workers into a companywide process of organizational learning.

Top managers had ultimate control over strategic investments, and technical specialists designed products and processes, typically on the basis of foreign technology. But given these managerial capabilities, the unique ability of Japanese companies to transform technology acquired from abroad to generate new standards of quality and cost depended not only on the abilities of their engineers but also on the integration of shop-floor workers into organizational learning. Through their engagement in forms of cost reduction, Japanese shop-floor workers were continuously involved in more general improvements of products and processes that, by the 1970s, enabled Japanese companies to emerge as world leaders in factory automation. Also of great importance was the ability of Japanese manufacturers to eliminate waste in production: by the late 1970s, for example, Japan's competitive advantage in television sets was not in labor costs, or even in scale economies, but in a savings of materials costs. This productive transformation became particularly important in international competition in the 1980 s as Japanese wages approached the levels of the advanced industrial economies of North America and Western Europe, and, especially from 1985, as the value of the yen grew dramatically stronger. During the 1980 os and 1990s, influenced not by only Japan's export performance but also by the impact of Japanese direct investment in North America and Western Europe, many Western companies sought, with varying degrees of success, to implement Japanese high-quality, low-cost mass-production methods. 
During the 1980s, most Western analyses of the sources of Japanese competitive advantage focused on the hierarchical integration of the shop-floor worker into organizational learning. By the early 1990s, the emphasis had shifted to the role of "cross-functional management," "company-wide quality control," or "concurrent engineering" in generating higher-quality, lower-cost products. The hierarchical integration of engineers with shop-floor workers fostered functional integration as specialized engineers engaged in teams to solve practical manufacturing problems.

Contrary to conventional wisdom, in terms of support for technology development, it was the U.S., not the Japanese, government that was the more formidable "developmental state." Indeed, through strategic alliances and licensing in the United States, the Japanese transferred back home technologies that were in part the result of massive investments in microelectronics that the U.S. government made in the post-World War II decades. In contrast, it was in the realm of finance, not technology, that the Japanese state played a developmental role by structuring the banking system as an investment institution to fund the high-speed growth of industrial enterprises during the postwar decades. While stable shareholding gave corporate managers strategic control over the allocation of corporate revenues in the post-World War II decades, even with low payout ratios corporate retentions were grossly insufficient to finance the capital requirements of Japanese companies in the era of high-speed growth. Using retentions as a foundation, most of the financial commitments of Japanese companies came from bank loans, and the companies' debt-equity ratios often reached three to one, and at times were even higher. In borrowing these funds, each major industrial company had a "main bank" whose job it was to convince other banks to join it in making loans to the company and to take the lead in restructuring its client company should it fall into financial distress.

In funding the growth of Japanese companies, the Japanese banks were relatively passive agents of government development policy while "overloans" were made by the Bank of Japan to its member banks for providing highly leveraged finance to growing industrial companies. The Japanese banks never had any significant capabilities to monitor these companies, as evidenced by their rush to make speculative loans during the bubble economy of the late 1980 os and their persistent baddebt burdens since the bubble burst in 1990. Japanese banks, that is, played a critical role in providing financial commitment, but they played no significant part in the exercise of strategic control. ${ }^{21}$

\footnotetext{
${ }^{21}$ Hence, my use of the more modest term "main bank lending," rather than the grandiose term "main bank system," to describe this institution.
} 
What then ensured that the top executives of Japanese companies would impose strategic control for the benefit of their companies, rather than for their own personal gain? It was not the board of directors, which in Japan was almost entirely made up of inside executives, and indeed functioned more as a body for bestowing honorific positions on aging top managers than for engaging in corporate decision-making or oversight. As occurred in the U.S. old-economy model at its innovative peak, the behavior of Japanese top managers was regulated by the cohesive organizations over which they presided, and in particular by the institution of permanent employment that carried with it the responsibility for maintaining the competitiveness of the company. Over time, norms of corporate behavior evolved in Japan that no top executive could defy. Even though permanent employment is not a contractual relation at the level of the firm, under the "doctrine of abusive dismissal" courts have demanded that employers demonstrate, subject to strict criteria, "a business need" for layoffs. By way of contrast, in the late 1980 s, in the wake of a rash of corporate downsizings, the U.S. labor movement had to wage a difficult, but ultimately successful, battle to persuade the U.S. Congress to pass a law requiring a company to give workers in plants with one hundred or more employees sixty days' notice that the facility was going to be closed.

\section{U.S. New-Economy Business Model ${ }^{22}$}

During the 1970 and 1980 , while Japanese enterprises were challenging established U.S. managerial corporations in many industries where they had been dominant, there was a resurgence of the U.S. information and communication technology industries, providing the foundation for what, by the last half of the 1990s, became known as the "new economy." Historically underlying the emergence of the new economy were massive post-World War II investments by the U.S. government, in collaboration with research universities and industrial corporations, in developing information and communication technologies. ${ }^{23}$

\footnotetext{
${ }^{22}$ This section draws upon Lazonick, Sustainable Prosperity in the New Economy? and references contained therein.

${ }^{23} \mathrm{On}$ the historical role of the U.S. government in the development of the computer industry, see Ernest Braun and Stuart MacDonald, Revolution in Miniature: The History and Impact of Semiconductor Electronics (Cambridge, U.K., 1982, 2nd ed.); Kenneth Flamm, Targeting the Computer: Government Support and International Competition (Washington, D.C., 1987), and Creating the Computer: Government, Industry, and High-Technology (Washington, D.C., 1988); Stuart Leslie, "How the West Was Won: The Military and the Making of Silicon Valley," in Technological Competitiveness: Contemporary and Historical Perspectives on the Electrical, Electronics, and Computer Industries, ed. William Aspray (New York, 1993), 75-89; David Mowery and Richard Langlois, "Spinning Off and Spinning On(?):
} 
By the end of the 1950s, this combined business-government investment effort had resulted in not only the first generation of computers, led by IBM, but also the capability of imbedding integrated electronic circuits in a silicon chip. Fairchild Semiconductor, Texas Instruments, and Motorola were in the forefront of creating the technology that would become the standard of the semiconductor industry. Through the early 1960 s, the U.S. government provided virtually all the demand for integrated circuits. From the second half of the 1960s, however, a growing array of commercial opportunities for electronic chips induced the creation of semiconductor startups. A new breed of venture capitalist, many with prior managerial or technical experience in the semiconductor industry, backed so many semiconductor startups clustered in the region around Stanford University that, by the early 1970s, the district was dubbed "Silicon Valley." Innovation in semiconductors, and especially the development of the microprocessor-in effect a computer on a chip-created the basis for the emergence of the microcomputer industry in the late 1970s, which in turn resulted in the enormous growth of an installed base of powerful "hosts" in homes and offices that made possible the Internet revolution of the 1990 s.

Intense, and often informal, learning networks that transcended the boundaries of firms contributed to the success of Silicon Valley. In the new-economy business model that emerged in Silicon Valley, professional managers, typically with engineering backgrounds, exercised strategic control. (See Figure 2.) Organizational learning occurred across firms, but it also, and I would argue more fundamentally, occurred within firms that integrated skill bases of highly educated personnel, enabling some particularly innovative enterprises, such as Intel, Sun Microsystems, Oracle, and Cisco Systems, to grow to employ tens of thousands of employees and to drive the development of the region.

In 2005, the top five hundred U.S.-based companies by sales included twenty information and communication technology firms, founded no earlier than 1959, that had been neither spun off from nor merged with an old-economy firm. These twenty companies had revenues ranging from $\$ 55.9$ billion for Dell Computer to $\$ 5.3$ billion for Yahoo!, with an average of $\$ 15.3$ billion. Their head counts ranged from 99,900 for Intel to 5,680 for Google, with an average of 36,062. Twelve of these twenty companies were based in Silicon Valley, another three

The Federal Government Role in the Development of the U.S. Computer Software Industry," Research Policy 25, no. 6 (1996): 947-66; Arthur Norberg and Judy O'Neill, Transforming Computer Technology: Information Processing for the Pentagon, 1962-1986 (Baltimore, 1996); National Research Council, Funding a Revolution: Government Support for Computing Research (Washington, D.C., 1999); and Janet Abbate, Inventing the Internet (Cambridge, Mass., 1999). 


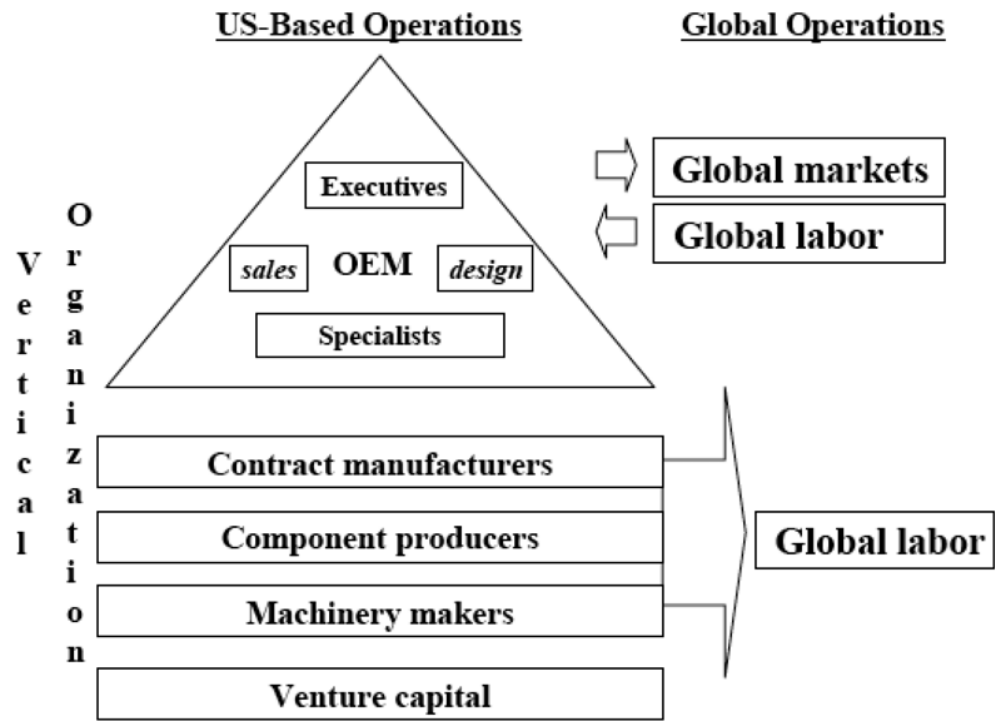

Figure 2. The U.S. new-economy business model, with its "flexible" organization of labor and capital.

in Southern California, and the others in five different states around the United States. ${ }^{24}$

It was, nevertheless, an old-economy company, IBM, that laid the foundations for the vertical specialization of the microcomputer industry when, in the early 1980 s, it elected to develop its personal computer, or PC, using Intel's microprocessors and Microsoft's operating system. The open-systems standards that resulted from the dominance of this "Wintel" architecture favored cross-licensing of technology, strategic alliances, and outsourcing of components, rather than in-house proprietary research and vertical integration of the supply chain. The adoption of open-systems standards provided the technological rationale for old-economy companies, such as IBM and Hewlett-Packard, to make the transition to the new-economy business model, thus assuring its dominance. Beginning in 2000, these two companies became the world's largest information and communication technology enterprises.

Innovative new-economy companies have tended to grow large by upgrading and expanding their product offerings within their main lines of business and, thus far at least, have not engaged in the indiscriminate diversification into unrelated technologies and markets that

\footnotetext{
${ }^{24}$ Lazonick, Sustainable Prosperity in the New Economy? 30-31.
} 


\section{William Lazonick / 694}

characterized, and ultimately undermined, the performance of many leading old-economy companies in the 1960s and 1970s. At the same time, new-economy companies have become less vertically integrated than old-economy companies, because equipment manufacturers, such as Cisco, Dell, and Sun Microsystems, have focused their investment strategies on activities that require organizational learning in their core competencies. At the same time, they have outsourced activities that, as in the case of semiconductor fabrication, are too expensive and complex to be done in house, or, alternatively, as in the case of printed circuit-board assembly, have become routine.

Some of the largest information and communication technology companies in the United States are upstream suppliers of electronics components; a number of them are in the Fortune 500, and some have tens of thousands employees. A main competitive advantage of the leading contract manufacturers is their ability to relocate production processes that have become cost sensitive and routine to lower-wage global locations. Indeed, the offshoring of routine production activities is a characteristic feature of the new-economy model. In the 1960s and 1970s, well before the rise of the contract manufacturers as an outsourcing option for the old-economy models, growing Silicon Valley companies took the lead in sending offshore more routine production processes, such as semiconductor assembly, especially to Asia.

Open systems under the new-economy business model undermined the old-economy rationale, based in proprietary technology, of providing employees with the expectation of career employment with one company. As a much reduced value came to be placed on in-house experience, companies favored the employment of younger people versed in the latest open-systems technologies. In addition, younger employees tended to be cheaper; increasingly in the 1990 s and 2000 and beyond, qualified, low-cost personnel could be found in low-wage areas of the world, such as China and India. Meanwhile, encouraged by U.S. work-visa programs, a strong flow of university-educated people arrived from these low-wage countries into the United States, seeking employment experience that would add to their qualifications and value if and when they returned back home. By 2000 and throughout that decade, the two-way flow of U.S. investment to Asian labor and Asian labor to jobs in the United States had resulted in a thoroughly globalized high-tech labor force.

The interfirm mobility of labor that became a prime feature of the new-economy business model had its origins in the ways in which, from the late 1960s, capital and labor were reallocated from established oldeconomy corporations to new-economy startups. The creation of NASDAQ in 1971 as a national electronic stock market encouraged venture- 
capital investments in new firms because the listing requirements on NASDAQ were far less stringent than those on the "old-economy" New York Stock Exchange. The existence of NASDAQ as an intensely speculative and yet highly liquid market provided venture capital with the possibility of a relatively quick exit from its investments in startups, and hence induced a flow of venture capital into what would become the new economy.

These high-tech startups then needed to convince professional, technical, and administrative personnel to eschew the security of career employment in the established old economy in order to take up inherently insecure jobs in the new economy. The main inducement offered by this allocation of labor services was the employee stock option, a form of compensation that would become valuable if and when the startup was able to launch an IPO, again typically on NASDAQ. The existence of a speculative and liquid national stock market, therefore, was central to the allocation of both capital and labor to the new economy as an alternative to the old economy.

Once listed on the stock market, a new-economy company tended to reinvest all its earnings in the growth of the firm, paying no dividends for at least the first decade after its IPO, and in many cases much longer. The only way of gaining a return on one's shareholdings, therefore, was by selling one's stock on the market. During the 1980 s and the first half of the 1990s, the main driver of the stock-price increases of these companies was innovation-that is, the generation of higher-quality, lower-cost products than had previously existed. In the Internet boom of the late 1990s, however, speculation became the main driver of their soaring stock prices, resulting in enormous gains not only for top executives but also for employees who could cash in their stock options.

Since 2000, however, these same companies have engaged in the manipulation of their stock prices through massive stock repurchases, often amounting to billions of dollars per year. Indeed, during the de-

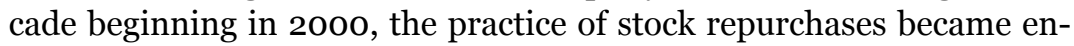
demic to the U.S. corporate economy as their scale and scope exploded. From 1997 through 2009, 438 companies in the S\&P 500 Index that were publicly listed in 1997 expended $\$ 2.8$ trillion on stock repurchases, an average of $\$ 6.4$ billion per company, while distributing a total of $\$ 2.0$ trillion in cash dividends, an average of $\$ 4.6$ billion per company. In 2007, these companies averaged $\$ 1,213$ million in repurchases and $\$ 533$ million in dividends. In 2008, repurchases fell substantially for these 438 companies, constrained by a dramatic decline in combined net income from $\$ 637$ billion in 2007 to $\$ 297$ billion in 2008. Nevertheless, their combined repurchases only declined from $\$ 531$ billion to $\$ 318$ billion. As a result, the repurchase-payout ratio increased from 


\section{William Lazonick / 696}

0.83 to 1.07. In addition, these companies paid out $\$ 16$ billion more in dividends in 2008 than in 2007 , with the result that the dividendpayout ratio leapt from 0.37 to 0.81 .

As a mode of distribution of corporate revenues to shareholders, repurchases are fundamentally different from dividends. Through dividend payments, shareholders reap returns from their financial investment by holding stock, whereas through repurchases shareholders reap returns on their financial investment by selling stock. Dividends are associated with financial stability, whereas repurchases are associated with financial volatility. Corporate executives argue that they conduct stock buybacks because the shares of the companies they manage are undervalued. But a company that carries out large-scale buybacks virtually never sells shares at higher prices to lock in the capital gains for the company, since to do so the company's executives would, in effect, be announcing to the stock market that they think the company's stock is overvalued. What often happens is that companies that have initiated large-scale buybacks subsequently sell their stock on the market at much lower prices because they have gotten into financial distress. ${ }^{25}$

Allocated differently, the trillions spent on buybacks in the past decades could have helped stabilize the economy. Many companies not only spent all their profits on repurchases but also even ate into their capital. The particular adverse impacts of stock buybacks on the achievement of equitable and stable growth varied across different sectors of the U.S. economy.

Among the biggest stock repurchasers in the years prior to the financial crisis were many of the banks that were responsible for the meltdown and were bailed out under the Troubled Asset Relief Program (TARP). They included Citigroup ( $\$ 41.8$ billion repurchased in 200007), Goldman Sachs ( $\$ 30.1$ billion), Wells Fargo ( $\$ 23.2$ billion), JP Morgan Chase ( $\$ 21.2$ billion), Merrill Lynch ( $\$ 21.0$ billion), Morgan Stanley ( $\$ 19.1$ billion), American Express ( $\$ 17.6$ billion), and U.S. Bancorp ( $\$ 12.3$ billion). In the eight years before it went bankrupt in 2008, Lehman Brothers repurchased $\$ 16.8$ billion, including $\$ 5.3$ billion in 2006-07. Washington Mutual, which also went bankrupt in 2008, expended $\$ 13.3$ billion on buybacks in 2000-07, including $\$ 6.5$ billion in 2006-07. Wachovia, ranked thirty-eighth among the Fortune 500 in 2007 , did $\$ 15.7$ billion in buybacks in 2000-07, including $\$ 5.7$ billion in 2006-07, before its fire sale to Wells Fargo at the end of 2008. Other major financial services companies that did substantial repurchases beginning in 2000, before they ran into financial distress in 2008, were AIG ( $\$ 10.2$ billion), Fannie Mae ( $\$ 8.4$ billion), Bear Stearns ( $\$ 7.2$ billion),

\footnotetext{
${ }^{25}$ Lazonick, "The New Economy Business Model.”
} 
and Freddie Mac ( $\$ 4.7$ billion). By spending money on buybacks during boom years, these financial corporations reduced their ability to withstand the crash of the derivatives market in 2008, thus exacerbating the jeopardy they created for the economy as a whole.

There has been virtually no public-policy debate in the United States over the practice of buybacks, its acceleration in recent years, or the implications for innovation, employment, income distribution, and economic growth. Exceptionally, in the summer of 2008, four congressional Democrats-Rep. Rahm Emanuel (IL), Rep. Edward Markey (MA), Sen. Robert Menendez (NJ), and Sen. Charles Schumer (NY)took aim at stock repurchases by the big oil companies, after Exxon Mobil, by far the largest repurchaser of stock ( $\$ 144$ billion in 2000o8), had announced record second-quarter profits of $\$ 11.7$ billion, of which $\$ 8.8$ billion went to stock buybacks. ${ }^{26}$ In a letter to oil-industry executives, the congressmen asked them to "pledge to greatly increase the ratio of investments in production and alternatives to the amount of stock buybacks this year and next by investing much more of [their] profits into exploration and production on the leases [they] have been awarded in the U.S., and in the research and development of promising alternative energy sources." ${ }^{27}$ Exxon Mobil did not pay much attention to this plea: in the last half of 2008, it repurchased another $\$ 17.5$ billion for a total of $\$ 35.7$ billion, or 79 percent of its net income, over the entire year. In 2009, Exxon Mobil did another $\$ 19.7$ billion in buybacks, equivalent to 102 percent of its net income for that year.

Meanwhile, in June 2010, a number of prominent business executives, as members of the American Energy Innovation Council, called for a tripling of U.S. government spending on clean-energy research to $\$ 16$ billion per year. ${ }^{28}$ In a New York Times article, John Doerr, a noted venture capitalist with the Silicon Valley firm of Kleiner, Perkins, Byers and Caufield and a member of the Council, was quoted as saying: "When our company shifted our attention to clean energy, we found the innovation cupboard was close to bare. My partners and I found [that] the best fuel cells, the best energy storage and the best wind technology were all born outside of the United States." ${ }^{29}$ Companies such as Bank of America, General Electric, and Microsoft, whose top executives are

${ }^{26}$ U.S. Congress, "Democrats Tell Big Oil: Spend More on Production and Renewable Energy, Less on Stock Buybacks before Making Demands for New Drilling Leases" (Washington, D.C., 31 July 2008); see also Kristen Hays and David Ivanovich, "Politicians Fume as Exxon Profits," Houston Chronicle, 1 Aug. 2008.

${ }^{27}$ U.S. Congress, "Democrats Tell Big Oil."

${ }^{28}$ American Energy Innovation Council, "A Business Plan for America's Energy Future," June 2010, available at http://www.americanenergyinnovation.org/full-report/.

${ }^{29}$ John Broder, "A Call to Triple U.S. Spending on Energy Research," New York Times, 9 June 2010. 


\section{William Lazonick / 698}

members of Council, have been among the largest repurchasers in the United States.

Among the top ten repurchasers of stock in 2000-08 were five of the leading information and communication technology companies: Microsoft (the number two repurchaser, with $\$ 94.3$ billion in buybacks), IBM (number three, with $\$ 72.9$ billion), Cisco Systems (number five, with $\$ 53.6$ billion), Intel (number eight, with $\$ 48.8$ billion), and Hewlett-Packard (number ten, with $\$ 43.3$ billion). All these companies spent more on buybacks than on research and development in 2000-08. Throughout the past decade, as we have seen, all these companies have been globalizing employment and profiting through the creation of high-tech jobs in lower-wage parts of the world, such as China and India, while using the profits of globalization to do stock buybacks at home. ${ }^{30}$

Meanwhile, U.S. high-tech companies lobby the U.S. government for more public investment in the U.S. high-tech knowledge base, even as the companies allocate their own profits to huge stock buybacks. For example, during the past decade, Intel, along with the Semiconductor Industry Association, pressured the U.S. Congress to increase spending on the National Nanotechnology Initiative. At a press conference that the Semiconductor Industry Association organized in Washington, D.C., in March 2005, Intel CEO Craig Barrett warned: "U.S. leadership in the nanoelectronics era is not guaranteed. It will take a massive, coordinated U.S. research effort involving academia, industry, and state and federal governments to ensure that America continues to be the world leader in information technology." ${ }^{11}$ Yet, in 2005, the annual National Nanotechnology Association budget was $\$ 1.2$ billion, just 11 percent of the $\$ 10.6$ billion that Intel spent on stock repurchases in that year alone. Indeed, Intel's 2005 expenditures on stock buybacks exceeded the total of $\$ 10.1$ billion that the U.S. government spent on NNI since its inception in 2001 through 2009. ${ }^{32}$ Given the extent to which the information and communication technology industry in general, and a company like Intel in particular, has benefited from decades of government investments in the high-tech knowledge base, one might ask whether a portion of the massive funds that Intel allocates to buying back

\footnotetext{
${ }^{30}$ William Milberg, "Shifting Sources and Uses of Profits: Sustaining U.S. Financialization with Global Value Chains," Economy and Society 37, no. 3 (2008): 420-51; Lazonick, Sustainable Prosperity in the New Economy?

${ }^{31}$ "U.S. Could Lose Race for Nanotech Leadership, SIA Panel Says," Electronic News, 16 Mar. 2005.

${ }^{32}$ In 2008, the NNI (national nanotechnology infrastructure) budget was $\$ 1.55$ billion with an estimated budget for 2009 of $\$ 1.65$ billion, and a proposed \$1.64 billion for 2010 . See the Web site www.nano.gov/html/about/funding.html.
} 
its own stock could not be more productively allocated "to ensure that America continues to be the world leader in information technology." 33

Among the largest repurchasers of stock during the past decade have been pharmaceutical companies. For 2000-08, Pfizer was the number seven repurchaser with $\$ 50.6$ billion in buybacks, Johnson \& Johnson was number twelve with $\$ 33.3$ billion, Amgen number twentyfour with $\$ 22.6$ billion, and Merck number thirty-one with $\$ 18.7$ billion. These and other U.S. pharmaceutical companies charge higher drug prices in the United States than in other rich nations, such as Japan, Canada, and France, because, their executives argue, they need the higher earnings to fund their research-and-development efforts in the United States. Yet the very same companies carry out massive stock buybacks for the sole purpose of manipulating their stock prices. Meanwhile, the United States is the world leader in biopharmaceuticals in large part because of $\$ 31$ billion per annum that the National Institutes of Health spend in support of the life-sciences knowledge base, as well as numerous government subsidies to the pharmaceutical industry, including financial support for medicines produced under the Orphan Drug Act of $1983 .{ }^{34}$ Instead of doing stock buybacks, the pharmaceutical companies could be contributing to the national life-sciences effort, or lowering their drug prices to make their products more affordable to the American public.

The only purpose of stock repurchases is to provide a manipulative boost to a company's stock price. The top executives who make these allocative decisions have much to gain from the practice: a substantial portion of their salaries comes from stock-based compensation, especially stock options. Since the 1970 s there has been an ongoing explosion in top executives' pay. According to AFL-CIO Executive Paywatch, the ratio of the average pay of CEOs of two hundred large U.S. corporations to the pay of the average full-time U.S. worker was 42:1 in 1980, 107:1 in 1990, 525:1 in 2000, and 319:1 in 2008. ${ }^{35}$ Already in the early 1990s, much was written about the outsized pay of top executives. Yet the main explosions were yet to come. Measured in 2008 dollars, averaged over 1992-94, the mean annual compensation of the three thousand highest-paid executives in U.S. corporations was $\$ 3.0$ million, of which 36 percent came from stock options, while in 2005-07, the mean annual compensation of this group was $\$ 9.2$ million, of which 47 percent came from stock options. For the five hundred

33 "U.S. Could Lose Race for Nanotech Leadership."

${ }^{34}$ William Lazonick and Öner Tulum, "U.S. Biopharmaceutical Finance and the Sustainability of the Biotech Business Model," Research Policy (forthcoming).

${ }^{35}$ AFL-CIO, Executive Paywatch (2009). See the Web site http://www.aflcio.org/corporate watch/paywatch/pay/index.cfm. 


\section{William Lazonick / 700}

highest-paid executives, mean annual compensation (in 2008 dollars) was $\$ 8.7$ million in 1992-94, 52 percent of which came from stock options, and $\$ 28.2$ million in 2005-07, 60 percent of which was from stock options. ${ }^{36}$

My view is that both the size and mode of top executive compensation in U.S. corporations are undermining the social conditions of innovative enterprise. ${ }^{37}$ U.S.-style stock-based executive compensation separates the interests of those who exercise strategic control from the rest of the corporate organization. It also subverts the process of organizational integration by sacrificing the interests of employees for the sake of booking profits. And it reduces financial commitment to investment in innovation. At the end of the first decade of the twenty-first century, the United States possesses the world's largest and, as yet, most powerful economy. It is, however, an economy fraught with inequity in its income distribution and instability in its employment opportunities. If the United States ever had an economy that other nations of the world hoped to emulate, such is not the case today. Americans themselves might want to raise the question about the viability of alternatives to the "new-economy" mode of capitalism that now prevails.

\section{Innovative Business Models and Economic Performance}

Superior economic performance entails the achievement of equitable and stable economic growth. Innovation-the generation of higherquality products at lower unit costs given prevailing factor pricesprovides the foundation for per-capita productivity growth and higher standards of living. Inequity in economic performance occurs when certain groups in the economy are able to extract more value than they create, thus making the distribution of income and wealth more unequal than is necessary for innovation to occur. Instability occurs when the extent of value extraction undermines the ability of governments and businesses to make the investment in productive capabilities that can result in innovation and related employment opportunities.

There is no doubt that since the 1980 os the new-economy business model has been an engine of innovation in the U.S. economy. Through venture-backed startups, new competitors have emerged in a range of high-tech industries. Flexible capital and labor markets have enabled the allocation of resources to these startups, and have permitted them to grow. Since the late 1970 , new-economy industry groups, such as

${ }^{36}$ William Lazonick, "The Explosion of Executive Pay and the Erosion of American Prosperity," Entreprises et Histoire 57 (2010): 141-64.

${ }^{37}$ Ibid. 
the National Venture Capital Association and the American Electronics Association, have been at the forefront of lobbying the U.S. Congress to lower capital-gains and personal-income tax rates and to deregulate capital and labor markets, all in the name of innovation. These industry groups demand that the government spend more on the human and physical infrastructure that will enable "America to compete," while failing to suggest that their corporate members incur any obligation to share the gains of innovative enterprise with the government-that is, the taxpayer-when innovation occurs.

In the twenty-first century, Hall and Soskice's characterization of the United States as a "liberal market economy" may be an apt description of what the U.S. variety of capitalism has become. If so, however, it is not a variety of capitalism that yields a high level of economic performance. As a "liberal market economy," even the most innovative sectors of the U.S. economy have become highly financialized as the allocation of corporate resources is being driven by the ideology of "maximizing shareholder value." By financialization, I mean the evaluation of the performance of a company by a financial measure, such as earnings per share. The manifestation of the financialization of the U.S. economy is the obsession of corporate executives with distributing "value" to shareholders, especially in the form of stock repurchases, even if this is done at the expense of investment in innovation and the creation of U.S. employment opportunities.

In the 1980 and 1990s, the rise of the new-economy business model, characterized by marketization and globalization, enhanced the potential of the U.S. economy to upgrade its innovative capability in response to international competition. By marketization, I mean that competitive market processes play a heightened role in the allocation of inputs to a company and the sale of outputs by a company. By globalization, I mean the breaking down of national barriers that face a company to the movement of goods, people, and money around the world. The marketization of both capital and labor permitted the reallocation of resources to new, innovative firms. ${ }^{38}$ The globalization of capital and labor permitted U.S.-based companies to focus their investments in the United States on higher value-added activities while offshoring lower value-added activities to lower-wage areas of the world. ${ }^{39}$

In the presence of marketization and globalization, however, the achievement of equitable and stable economic growth in the United States required more, not less, coordinated investment by business and government in developing the capabilities of the U.S. labor force as a

\footnotetext{
${ }^{38}$ Lazonick, Sustainable Prosperity in the New Economy? ch. 2.
}

${ }^{39}$ Ibid., ch. 5 . 


\section{William Lazonick / 702}

whole and in ensuring the availability of new employment opportunities to make use of those capabilities. Over the past decade, the financialization of the U.S. business corporation has undermined the innovative potential of marketization and globalization, thus not only exacerbating inequity and instability but also restricting the potential for economic growth. ${ }^{40}$ Despite the financial meltdown of 2008, there are scant signs some two years later of institutional changes that will constrain the destructive behavior of financialized corporations.

\footnotetext{
${ }^{40}$ Ibid.; Lazonick, “The New Economy Business Model and the Crisis of U.S. Capitalism.”
} 